\title{
An Overview of Studies on Meiofaunal Traits of the Littoral Zone of Lakes
}

\author{
Marco Cifoni ${ }^{1}$, Angela Boggero ${ }^{2}$ (D) Diana Maria Paola Galassi ${ }^{3}$ (D) and Tiziana Di Lorenzo ${ }^{1, *(\mathbb{D})}$ \\ 1 National Research Council-Research Institute on Terrestrial Ecosystems (CNR-IRET), Via Madonna del \\ Piano, 10, 50019 Sesto Fiorentino, Florence, Italy; marco.cifoni@iret.cnr.it \\ 2 National Research Council-Water Research Institute (CNR-IRSA), Corso Tonolli 50, 28922 Verbania, Italy; \\ angela.boggero@cnr.it \\ 3 Department of Life, Health and Environmental Sciences, University of L'Aquila, Via Vetoio 1, 67100 Coppito, \\ L'Aquila, Italy; dianamariapaola.galassi@univaq.it \\ * Correspondence: tiziana.dilorenzo@cnr.it; Tel.: +39-055-522-5918
}

Citation: Cifoni, M.; Boggero, A.; Galassi, D.M.P.; Di Lorenzo, T. An Overview of Studies on Meiofaunal Traits of the Littoral Zone of Lakes. Water 2021, 13, 473. https://doi.org/ $10.3390 / w 13040473$

Academic Editor: Maria Mimikou

Received: 17 December 2020

Accepted: 8 February 2021

Published: 11 February 2021

Publisher's Note: MDPI stays neutral with regard to jurisdictional claims in published maps and institutional affiliations.

Copyright: (c) 2021 by the authors. Licensee MDPI, Basel, Switzerland. This article is an open access article distributed under the terms and conditions of the Creative Commons Attribution (CC BY) license (https:// creativecommons.org/licenses/by/ $4.0 /)$.

\begin{abstract}
We carried out an overview of the studies on the traits of the meiofauna of the littoral zone of lakes to investigate the question relating to the Raunkiaeran shortfall (lack of knowledge on biological traits). For this purpose, we selected a series of keywords associated with response and effect traits (feeding habits, locomotion and substrate relation, body size, shape and mass, life history, reproductive strategy, respiration and thermal tolerance) and we counted the relative frequency of occurrence in a set of scientific papers retrieved from Web of Science. The results showed that, except for the traits related to diet and feeding habits, the Raunkiaeran shortfall is very pronounced for all meiofaunal taxa of the littoral zone of lakes, especially for those related to soft-bodied organisms. The reason behind this deficiency concerns many aspects ranging from the high taxonomic expertise required to the intrinsic difficulties of observing organisms of such a small size. The relationship with temperature has not been sufficiently explored and formalized in any of the examined traits; this research aspect needs to be rapidly addressed since the prospects of climate change impacts on lake littorals are expected to be particularly severe.
\end{abstract}

Keywords: response traits; effect traits; taxonomy-based; meiobenthos; invertebrates

\section{Introduction}

Freshwater ecosystems are increasingly subject to frequent and intense threats which are caused directly or indirectly by humans [1,2]. The main threats concern overexploitation, pollution, water flow modification, destruction or degradation of habitats and introduction of invasive alien species [3]. Interacting threats in freshwater ecosystems lead to multiple alterations [4] and a massive biodiversity loss with a strong impact on the quality and quantity of the related ecosystem services [5]. Biomonitoring is the "par excellence" tool to assess the impacts of the threats on aquatic ecosystems, both on a large and small scale [6]. The biomonitoring of freshwaters is traditionally based on a taxonomic approach that evaluates the status of river, lake, and groundwater ecosystems by assessing the taxonomic richness, species composition and abundance distribution of the biological assemblages [7]. However, trait-based studies have gained increasing importance in recent times. Traits are measurable functional properties of an organism (or species, population and even community), such as body size, longevity, or type of diet [8]. Most traits are quantitative and directly measurable on an individual, while others are categorical (e.g., feeding habits). Functional traits can be divided into response and effect traits, where the response traits refer to the way an organism respond to certain environmental factors, while the effect traits are the contributions of an organism, species or population to ecosystem functioning $[9,10]$. Integrated response and effect traits have proved to be very useful to disentangle environmental dynamics influencing the ecological organization 
and ecosystem services [11] and to determine the extent of ecosystem perturbations [12]. Taken individually, both the taxonomy- and the trait-based biomonitoring provide partial information about an ecosystem [13], while the combination of the two approaches better describes the ecosystem status as well as the ability to predict changes in key ecosystem processes under variable environmental conditions (e.g., [10,14]). Integrated approaches allow to "incorporate more ecology into ecological risk assessment" [15]. Trait-based approaches deepen the environmental risk assessment, offering information on multiple aspects such as life-history and food web relations (e.g., [16]).

To date, the analyses of functional traits in freshwater ecosystems have mainly concerned macroinvertebrates, particularly in lotic ecosystems, with studies related to habitat alterations induced by anthropogenic pressures (e.g., [17]). However, the trait-based approach can be applied to any environment and any biological assemblage. Meiofauna are broadly defined as organisms smaller than $0.5 \mathrm{~mm}$ [18] comprising several taxa, such as microscopic protists, rotifers, nematodes, oligochaetes, microcrustaceans and larval chironomids, but also tardigrades, gastrotrichs and microturbellarians. Meiofauna are ubiquitous, can live among sand grains, interstitial pores, biofilms, and detrital particles [19] and play a complex and important role in benthic food webs (e.g., [20,21]). Some meiofaunal taxa, like rotifers, tardigrades, and nematodes, can withstand adverse conditions such as desiccation, high temperatures and radiation [22]. Studies concerning meiofauna, published from 2000 to 2018, focused mainly on marine environments (72\%) and to a lesser extent on freshwater environments (22\%), while only $1 \%$ of them considered meiofauna investigations falling within the broader field of limnology [19]. Most of these studies concerned nematodes (e.g., [23]), while the remaining meiofaunal taxa have been underexamined. Finally, trait-based multimetric analyses (i.e., analyses based on the information deriving from the examination of several traits), constitute a more recent approach [24] and are not yet fully developed for all taxa of limnic meiofauna [19].

Based on the studies carried out on marine and freshwater ecosystems, it is expected that the meiobenthos may play a pivotal role in lake ecosystems as well, especially in the littoral zones where they may contribute for one quarter to over $90 \%$ of the total energetic budget ([25] and references therein). For instance, because of short population turnover rates, meiofauna can quickly respond to environmental changes in lakes, encompassing water level, dissolved oxygen, temperature, and nutrient dynamics variations [19]. In this study we reviewed the scientific publications concerning the meiofauna of the littoral zone of lakes (an area that goes from the shore to the euphotic zone), to investigate one of the seven meiofaunal biodiversity shortfalls [26], namely the Raunkiaeran shortfall (lack of knowledge about biological traits). For this purpose, we selected fifty-five keywords, of which three associated with taxonomy-based approaches and fifty-two associated with response and effect traits, with particular reference to feeding habits, locomotion and substrate relations, diet, body size, shape and mass, life history, reproductive strategy, respiration and thermal tolerance. We analyzed and synthesized the data also considering their relevance to response and effect traits. Finally, we analyzed the data to provide an overview of research trends in the past years and identify research gaps in the use of meiofaunal traits in the biomonitoring of the littoral zone of lakes.

\section{Materials and Methods}

The entire methodological procedure is shown in the flow chart of Figure 1.

We assembled a list of fifty-two keywords associated with response and effect traits using glossaries of books and papers focused on ecology, aquatic ecology, stream ecology, population ecology and invertebrate zoology (full list in Figure 2 and Supplementary File; KEYWORDS). 

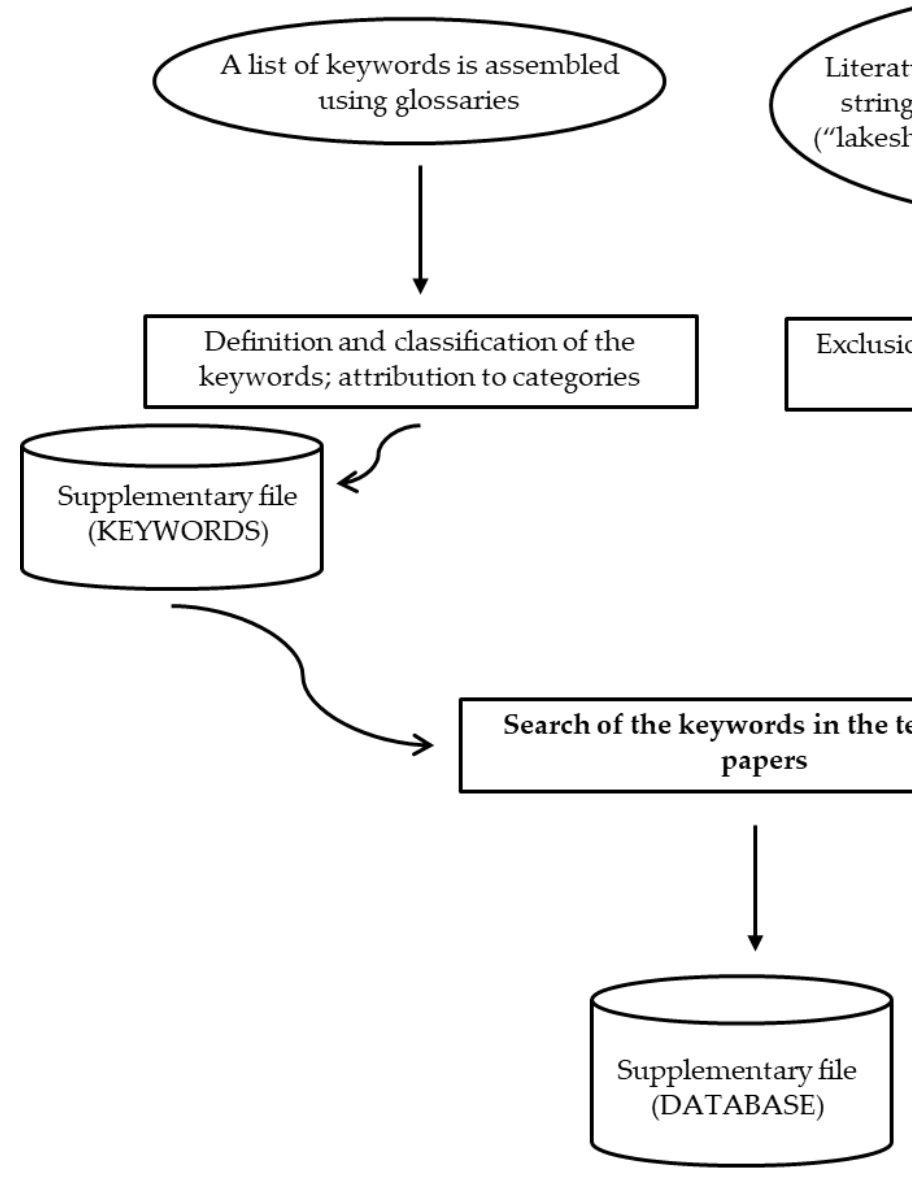

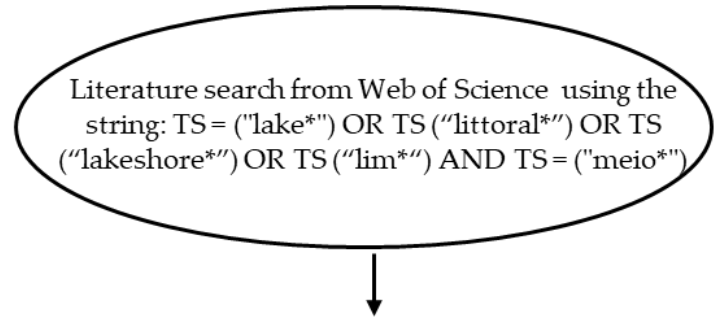

Exclusion of grey literature; selection of 62 papers concerning the meiofauna of the littoral zone of lakes

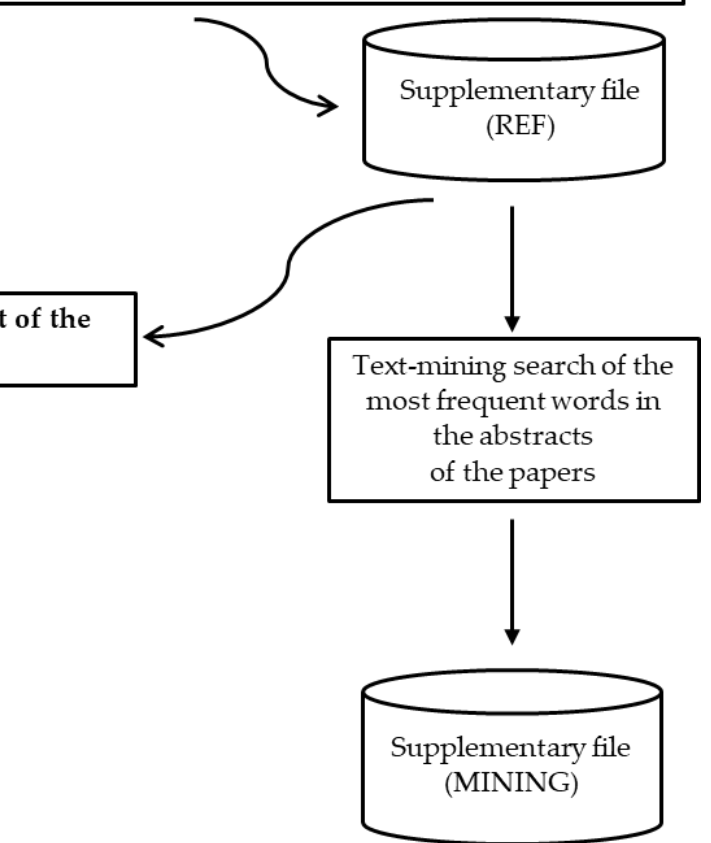

Figure 1. Flow chart of the methodological processes. The ovals indicate the initial phases, the rectangles represent the processes (the main process is in bold) and the cylinders indicate the databases.

Each keyword was referred to one of the following classes of traits: (1) "feeding habits"; (2) "locomotion and substrate relation"; (3) "diet"; (4) "body size, shape and mass"; (5) "life history"; (6) "reproductive strategy"; (7) "respiration"; (8) "thermal preference". The traits were also grouped into two categories: effect traits (classes 1 and 2 ) and response traits (all the remaining classes). "Feeding traits" were considered effect traits related to the trophic position of a taxon and describe aspects of the morphology and behavior associated with the diet. "Diet" was intended as a response trait since meiofaunal species can seasonally switch their type of food thereby shifting between trophic levels, irrespectively of their size (e.g., [20]). "Locomotion and substrate relation" were considered behavioral traits that respond to environmental change without any associated variations to physiological or morphological phenotypes. "Body size, shape and mass" and "respiration" (this latter investigated through the keywords "(in)tegument", "gill", "plastron" and "spiracle") were intended as morphological response traits which are important in mediating the interactions with the abiotic and biotic environment. "Life history" and "reproductive strategy" were considered response traits that describe the age schedule of an organism and key reproductive aspects such as age at maturity, clutch size, voltinism, life span, etc. Finally, "thermal preference" was intended as a physiological response trait related to the functional abilities of an organism, with a potential impact on fitness. To attribute the classes to the categories of response and effect traits, we followed the study of Moretti et al. [10] and others trait-based studies carried out on the meiofauna of lakes [24], rivers [27,28], hyporheic zones of rivers [29] and groundwater [14,30]. Some of the fifty-two keywords 
related to the above traits were composed of more than one word (for example: "raptorial feeders"). See Figure 2 and Table 1 for reference to the keywords and the classes and categories of the related traits. In addition to the fifty-two keywords referring to the response and effect traits, we selected the words "abundance", "diversity" and "density", which are the three keywords mainly used in studies conducted with taxonomy-based approaches.

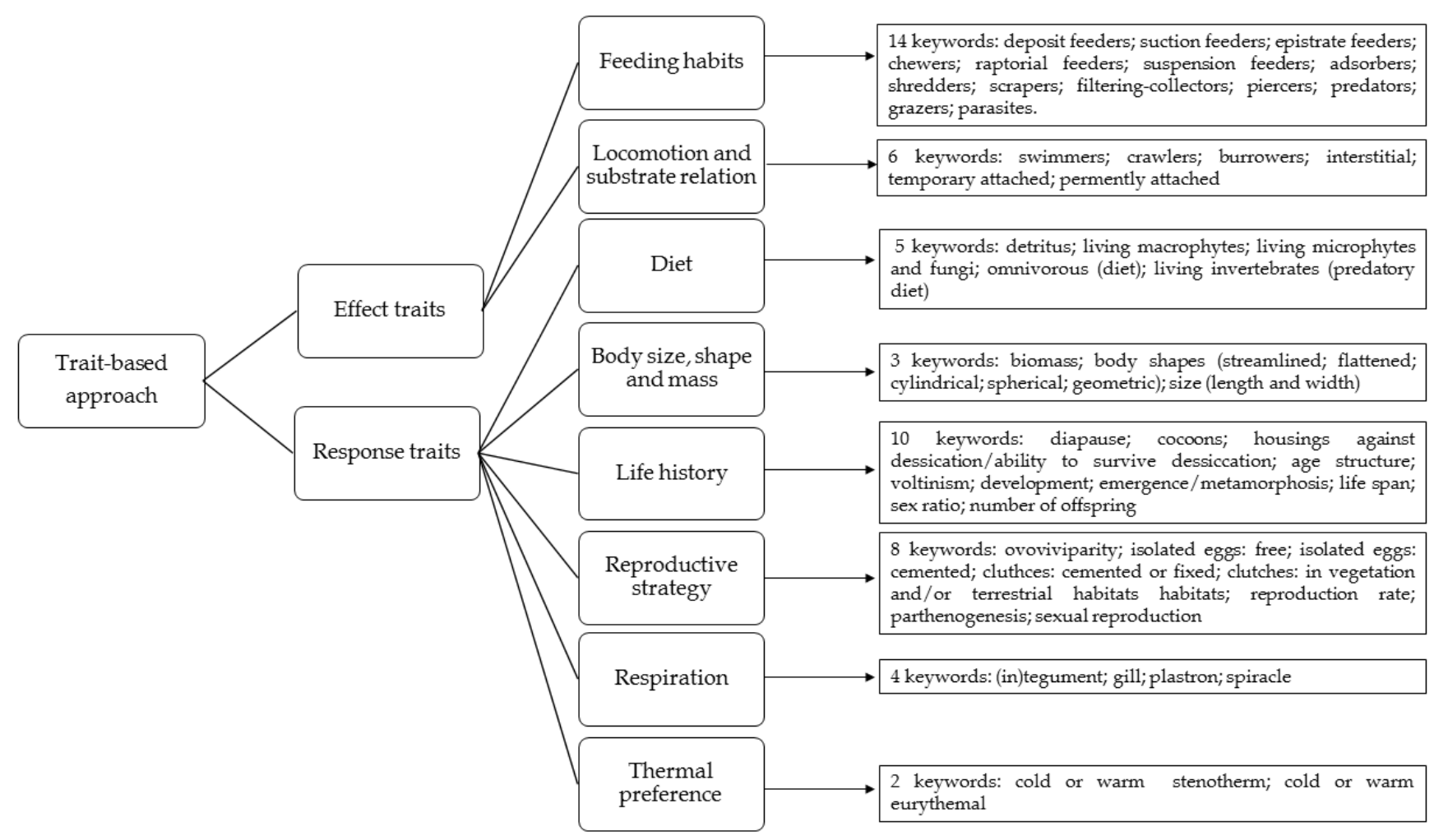

Figure 2. Framework of the trait keywords.

A set of selected scientific papers was retrieved from Web of Science (Clarivate Analytics) using the Google Chrome browser [31]. In the beginning, we did not restrict the search and we used the following wide string which referred to the meiofauna of the littoral zone of both fresh and brackish water lakes and limnic environments in general: TS = ("lake $\left.{ }^{* \prime}\right)$ OR TS ("littoral") OR TS ("lakeshore*") OR TS ("lim*") AND TS = ("meio*"). The string was in the Web of Science annotation, where: (i) TS indicates the searches made for 'topics' and (ii) the asterisk $\left(^{*}\right)$ is a symbol that commands to find all the words that include the string of characters indicated. Of the extracted papers, we excluded grey literature by considering only the papers written in English and published in indexed international scientific journals with impact factors. We also selected only the articles concerning the meiofauna of the littoral zone of freshwater lakes. The selected papers were stored in a database (Figure 1) containing the following fields: "Authors", "Article Title", "Source Title", "Abstract", "Year of publication", "Volume", "Number", "DOI" and "UT (Unique WOS ID). Some key aspects of the studies (e.g., the geographical coverage, ecological features of the lakes and methodologies) were also noted and reported in the database provided in the Supplementary File (REF). The pdf files of the articles were downloaded, numbered, and stored in a folder for the purposes of the subsequent keyword-searching phase. 
Table 1. Relative frequency of occurrence (RFO) of the trait keywords in the 62 papers concerning the meiofauna of the littoral zone of lakes. Cat: category; Cl.: class; R: response trait; E: effect trait; D: diet; BD: body size, shape and mass; LH: life history; RS: reproductive strategy; Re: respiration; TP: thermal preference; FH: feeding habits; L: locomotion and substrate relation.

\begin{tabular}{|c|c|c|c|c|c|c|c|}
\hline Cat. & Cl. & Keyword & RFO & Cat. & $\mathrm{Cl}$. & Keyword & RFO \\
\hline $\mathrm{R}$ & $\mathrm{D}$ & Detritus & $22.3 \%$ & E & $\mathrm{FH}$ & Deposit feeders & $22.5 \%$ \\
\hline $\mathrm{R}$ & $\mathrm{D}$ & Living macrophytes & $19.0 \%$ & $\mathrm{E}$ & $\mathrm{FH}$ & Epistrate feeders & $22.5 \%$ \\
\hline $\mathrm{R}$ & $\mathrm{D}$ & $\begin{array}{l}\text { Living microphytes and } \\
\text { fungi }\end{array}$ & $19.0 \%$ & $\mathrm{E}$ & $\mathrm{FH}$ & Suction feeders & $22.5 \%$ \\
\hline $\mathrm{R}$ & $\mathrm{D}$ & Omnivorous (diet) & $19.0 \%$ & $\mathrm{E}$ & $\mathrm{FH}$ & Chewers & $22.5 \%$ \\
\hline $\mathrm{R}$ & $\mathrm{D}$ & $\begin{array}{l}\text { Living invertebrates } \\
\text { (Predatory diet) }\end{array}$ & $20.7 \%$ & $\mathrm{E}$ & $\mathrm{FH}$ & Grazers & $4.9 \%$ \\
\hline $\mathrm{R}$ & $\mathrm{BD}$ & Biomass & $56.8 \%$ & E & $\mathrm{FH}$ & Predators & $0.0 \%$ \\
\hline $\mathrm{R}$ & $\mathrm{BD}$ & Body shapes & $18.2 \%$ & E & $\mathrm{FH}$ & Filtering-collectors & $1.1 \%$ \\
\hline $\mathrm{R}$ & $\mathrm{BD}$ & Size (lenght and width) & $25.0 \%$ & $\mathrm{E}$ & $\mathrm{FH}$ & Raptorial feeders & $1.1 \%$ \\
\hline $\mathrm{R}$ & $\mathrm{LH}$ & Development & $0.0 \%$ & $\mathrm{E}$ & $\mathrm{FH}$ & Suspention feeders & $1.1 \%$ \\
\hline $\mathrm{R}$ & $\mathrm{LH}$ & Age structure & $27.3 \%$ & $\mathrm{E}$ & $\mathrm{FH}$ & Shredders & $0.0 \%$ \\
\hline $\mathrm{R}$ & $\mathrm{LH}$ & Sex ratio & $18.2 \%$ & $\mathrm{E}$ & $\mathrm{FH}$ & Scrapers & $0.0 \%$ \\
\hline $\mathrm{R}$ & $\mathrm{LH}$ & Emergence/metamorphosis & $9.1 \%$ & $\mathrm{E}$ & $\mathrm{FH}$ & Parasites & $0.0 \%$ \\
\hline $\mathrm{R}$ & $\mathrm{LH}$ & Life span & $13.6 \%$ & E & $\mathrm{FH}$ & Adsorbers & $0.0 \%$ \\
\hline $\mathrm{R}$ & $\mathrm{LH}$ & Voltinism & $9.1 \%$ & $\mathrm{E}$ & $\mathrm{FH}$ & Piercers & $0.0 \%$ \\
\hline $\mathrm{R}$ & $\mathrm{LH}$ & Diapause & $9.1 \%$ & E & $\mathrm{L}$ & Interstitial & $57.1 \%$ \\
\hline $\mathrm{R}$ & $\mathrm{LH}$ & Number of offspring & $9.1 \%$ & E & $\mathrm{L}$ & Swimmers & $14.3 \%$ \\
\hline $\mathrm{R}$ & $\mathrm{LH}$ & Cocoons & $4.5 \%$ & E & $\mathrm{L}$ & Crawlers & $14.3 \%$ \\
\hline $\mathrm{R}$ & $\mathrm{LH}$ & $\begin{array}{l}\text { Housings against } \\
\text { dessication }\end{array}$ & $0.0 \%$ & $\mathrm{E}$ & $\mathrm{L}$ & Burrowers & $14.3 \%$ \\
\hline $\mathrm{R}$ & RS & Sexual reproduction & $54.5 \%$ & E & $\mathrm{L}$ & Temporary attached & $0.0 \%$ \\
\hline $\mathrm{R}$ & RS & Parthenogenesis & $27.3 \%$ & $\mathrm{E}$ & $\mathrm{L}$ & Permanently attached & $0.0 \%$ \\
\hline $\mathrm{R}$ & RS & Isolated eggs: free & $9.1 \%$ & & & - & \\
\hline $\mathrm{R}$ & RS & Reproduction rates & $9.1 \%$ & & & - & \\
\hline $\mathrm{R}$ & RS & Cluthces: cemented or fixed & $0.0 \%$ & & & - & \\
\hline $\mathrm{R}$ & RS & Clutches: in vegetation ... & $0.0 \%$ & & & - & \\
\hline $\mathrm{R}$ & RS & Isolated eggs: cemented & $0.0 \%$ & & & - & \\
\hline $\mathrm{R}$ & RS & Ovoviviparity & $0.0 \%$ & & & - & \\
\hline $\mathrm{R}$ & $\operatorname{Re}$ & (In)tegument & $100.0 \%$ & & & - & \\
\hline $\mathrm{R}$ & $\operatorname{Re}$ & Gill & $0.0 \%$ & & & - & \\
\hline $\mathrm{R}$ & $\operatorname{Re}$ & Plastron & $0.0 \%$ & & & - & \\
\hline $\mathrm{R}$ & $\operatorname{Re}$ & Spiracle & $0.0 \%$ & & & - & \\
\hline $\mathrm{R}$ & $\mathrm{TP}$ & Cold or warm stenotherm & $0.0 \%$ & & & - & \\
\hline $\mathrm{R}$ & $\mathrm{TP}$ & Cold or warm eurythemal & $0.0 \%$ & & & - & \\
\hline
\end{tabular}

We analyzed the semantic field of the studies through a text-mining search, identifying the most frequently used words in the abstracts (Figure 1). Numbers, punctuations, common English stop words and conjunctions were removed from the text data. These analyses were performed through $\mathrm{R}$ (ver. 3.5) computational framework [32] using packages $t m$ [33], SnowballC [34] and wordcloud [35].

Finally, we searched for the 55 keywords previously described (of which fifty-two referring to the trait-based approaches and three referring to the taxonomy-based approaches) in each of the selected papers, by carefully reading the papers. To verify that a keyword was contained in the text we used the "Advanced search" tool from the "Edit" menu of Adobe Acrobat Reader DC. For each keyword found, we noted the meiofaunal taxon which it referred to and the year of publication.

\section{Results}

The initial search produced 355 published papers, of which $48 \%$ in the "Marine and Freshwater Biology" field. At the end of the screening, 62 papers were obtained covering the years 1995-2020, strictly related to the meiofauna of the littoral zone of freshwater lakes. The papers concerned 21 countries worldwide. About $70 \%$ of the studies were carried out 
in Europe, mainly in Germany and Sweden. In particular, the meiobenthos of the littoral zone was investigated in 260 lakes, of which 193 (74\%) located in Europe: 122 in northern Europe (93 in Sweden, 25 in Finland, 2 in Estonia, 3 in Poland and 1 in Netherland), 61 in central (60 in Germany and 1 in France) and 10 in southern Europe (5 in Italy and 5 in Croatia). The remaining 67 (26\%) investigated lakes were located in North America (22 in Canada, Southern Quebec, and 3 in the U.S.A.), in South America (1 in Colombia, 2 in Ecuador and 1 in the Galapagos Archipelago), Russia (1 lake in Siberia) and Asia (2 in China and 1 in Thailand). The meiobenthos of the lake littorals was investigated in just one lake in Australia, Africa, and Antarctica. The characteristics of the investigated lakes were very variable in terms of size (from $<1 \mathrm{~km}^{2}$ to tens of thousands of $\mathrm{km}^{2}$ ) and depth (from $1.5 \mathrm{~m}$ to about $700 \mathrm{~m}$ ). Information on the ecological characteristics of the lakes was not reported in approximately 25\% of the studies (Supplementary File; REF). Cumulatively, the meiobentos of the lake littorals was studied in 397 monitoring stations, of which $32 \%$ was in a eutrophic status, $30 \%$ in a mesotrophic and $37 \%$ in an oligotrophic status. The size of the catchment area was reported for just 30 lakes out of 260 (14\% of the papers) and varied in the range $1-276,000 \mathrm{~km}^{2}$ The anthropogenic activities affecting the meiobenthos was reported for 25 lakes out 260 (11\% of the papers) and included agriculture, rapidly growing urban population, paper mills, crude oil pollution and tourism. Most of the papers (83\%) dealt with observational studies; experimental studies with mesocosms were performed to investigate the functional traits of the meiobenthos of 12 lakes, of which 11 located in central and northern Europe. In all studies, the taxonomic investigations were morphological and no genetic approaches were used or explored (Supplementary File; REF).

The result of the text-mining search can be viewed in the Supplementary File (MINING). The most frequent words were: (i) lake; (ii) nematod*; (iii) communiti*; (iv) speci*, abund ${ }^{*}$, sediment ${ }^{*}$, studi $^{*}$, from $^{*}$; (v) differ ${ }^{*}$, biomass ${ }^{*}$, meiofaun $^{*}$, domin $^{*}$ and effect ${ }^{*}$. The asterisk $\left(^{*}\right)$ indicates that the term represented in the word cloud includes all the words that contain the character string that precedes it. The raw data of the keyword search can be found in the Supplementary File (DATABASE).

Regarding the taxonomy-based approaches, 57 out of 62 studies considered at least one index of abundance, diversity, or density. The three keywords were used 127 times and $43.3 \%$ of the times they were referred to abundance indices, $33.1 \%$ to diversity indices and $23.6 \%$ to density values. In the taxonomy-based approaches, the most investigated invertebrate taxon was Nematoda (frequency of occurrence: $17.9 \%$ ), followed by Copepoda $(11.5 \%)$, Oligochaeta and Ostracoda $(9.9 \%)$, Rotifera $(9.5 \%)$, Cladocera $(7.6 \%)$, Chironomidae (7.3\%) and Tardigrada (5.7\%). Other taxa, such as Gastrotricha, Platyhelminthes, Gastropoda, Bivalvia, Amphipoda, Isopoda (juvenile stages $<500 \mu \mathrm{m}$ ), Acari Hydracnidia and Protista Ciliata, occurred with a frequency $<5 \%$. Nematodes were investigated in 47 papers, copepods in 30 and the remaining taxa in less than 30 papers (Figure 3 ).

Concerning the trait-based approaches, 52 out of 62 studies considered at least one response trait. The keywords of the response trait classes were used 199 times, overall. Most of the occurrences (73\%) of these keywords were recorded in the papers relating to 153 European lakes, of which 93 in Sweden and 60 in Germany (Supplementary File; GEO). The response traits of the meiofauna of the littoral zone of the lakes were investigated in 19 out of the 21 countries which the 62 papers referred to (Supplementary File; GEO). The most investigated classes were "diet" (frequency of occurrence: 60.8\%) and "body size, shape and mass " $(22.1 \%)$. With the exception of the "thermal preference" class, whose keywords were never mentioned in the 62 studies, the remaining classes ("life history", reproductive strategy" and "respiration") have been much less investigated (frequency of occurrence $\leq 11.0 \%$ ). Regarding the "diet" class, the related five keywords were equally used (relative frequency of occurrence-RFO—in Table 1). 


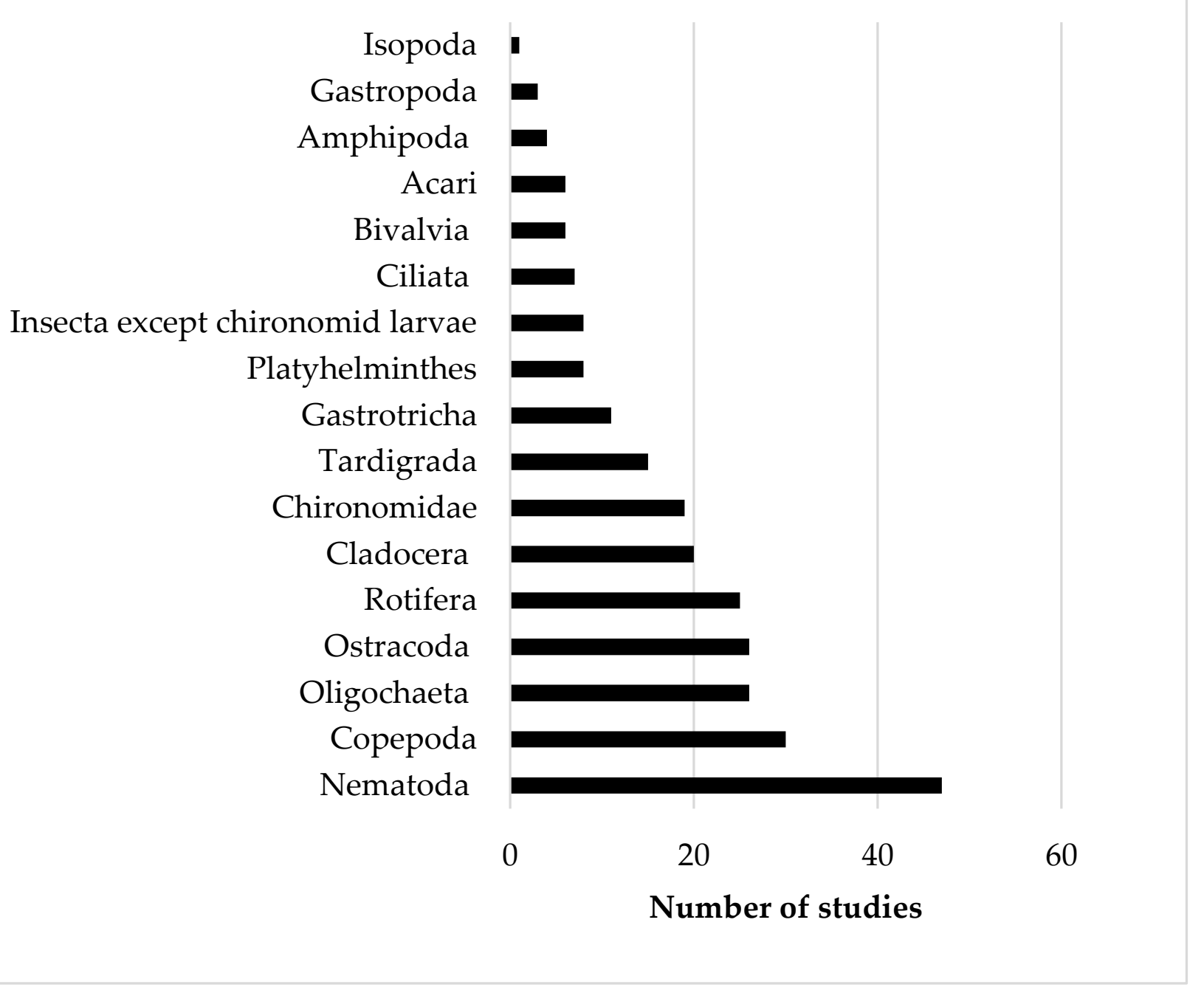

Figure 3. Number of taxonomy-based studies concerning the meiofaunal taxa of the littoral zone of freshwater lakes from 1995 to 2020.

Concerning the "body size, shape and mass" class, of the three related keywords, "biomass" was the most used (RFO: 56.8\%; Table 1). Regarding the "life history" class, of the ten keywords, the most used one was "age structure" (RFO $=27.3 \%)$ followed by "sex ratio" (RFO $=18.2 \%)$, while the remaining eight keywords were less used (RFO in Table 1 ) or not mentioned at all ("development", "housings against desiccation/ability to survive desiccation"). Of the eight keywords in the "reproductive strategy" class, "sexual reproduction" was the most used (RFO $=54.5 \%)$ followed by "parthenogenesis" ( $\mathrm{RFO}=27 \%$;), while "ovoviviparity", "isolated eggs: cemented or free clutches: cemented or fixed", "clutches: in vegetation and/or terrestrial" were never used (Table 1). "Integument" was the only used keyword of the "respiration" class (Table 1). The raw data can be found in the Supplementary File (DATABASE).

Concerning the effect traits, 30 out of 62 analyzed papers considered at least one of the two classes of effect traits. Overall, the keywords of the effect trait classes were used 96 times. Most of the occurrences (83\%) of these keywords were recorded in the papers relating to 153 European lakes, of which 93 in Sweden and 60 in Germany (Supplementary File; GEO). The effect traits of the meiofauna of the littoral zone of lakes were investigated in 8 out of the 21 world countries which the 62 papers referred to (Supplementary File; 
GEO). The "feeding habits" class was the most investigated (frequency of occurrence: $92.7 \%$ ) compared to the "locomotion and substrate relation" class. As for the "feeding habits" class, the relative frequency of occurrence of four keywords was $22.5 \%$ ("deposit feeders", "epistrate feeders", "suction feeders", "chewers"; Table 1); it was < 5\% for four keywords (Table 1) and it was equal to $0 \%$ for five other keywords ("shredders", "scrapers", "parasites", "adsorbers" and "piercers"). Within the "locomotion and substrate relation" class, the keyword with the highest frequency of occurrence was "interstitial" $(\mathrm{RFO}=57.1 \%)$, followed by "swimmers", "crawlers" and "burrowers" (each keyword with $\mathrm{RFO}=14.3 \%$ ), while the keywords "temporary attached" and "permanently attached" were never found (Table 1).Thirty-four keywords related to traits were associated with at least one taxon, while the remaining 18 keywords were not associated with a particular taxon but rather referred to the generic words "meiofauna" or "meiobenthos" (Figure 4a,b).

The frequency of occurrence of the keywords of both effect and response traits increased over time almost linearly. Concerning the trait-based approaches, Nematoda was the most studied taxon ( $25 \%$ of the studies carried out), followed by Copepoda and Cladocera (14.5 and 13.6\%, respectively). The response and effect traits associated with Gastrotricha, Rotifera, Oligochaeta, Tardigrada, Ostracoda and Chironomidae were investigated on average in $5 \%$ of the total number of studies, while the traits of Platyhelminthes, Gastropoda, Bivalvia, Amphipoda and Isopoda (juvenile stages $<500 \mu \mathrm{m}$ ), Acari Hydracnidia, Insecta (except chironomid larvae) and Protista Ciliata were investigated in less than $2.3 \%$ of the 62 papers considered.

The keywords of the effect traits "living invertebrates (predatory diet)", "living macrophytes", "living microphytes, fungi, etc.", "deposit feeders", "epistrate feeders", "suction feeders (omnivorous)", "chewers", "grazers" and "raptorial feeders", concerning the "feeding habits" effect trait and the "diet" response trait, were associated with 13 or 14 taxa (Figure 4a). The keywords of the response traits associated with the largest number of taxa were "biomass" and "detritus" (associated with 17 and 16 taxa, respectively; Figure 4b). The remaining keywords were associated with less than 12 taxa. Copepoda was the taxon with the highest number of associated keywords (28), followed by Nematoda and Cladocera (26). Bivalvia, Isopoda and Amphipoda (juvenile individuals) were associated with 5 keywords or less.

During the period 1995-2020, the increase of studies related to taxonomy-based approaches (2.4 articles/year) was greater than that of the trait-based ones (2.1 articles/year). The number of papers based on mixed approaches has increased by the same number per year (2.0 articles/year). In particular, the number of studies increased substantially after 2004 and 2011. The number of studies concerning Rotifera, Tadigrada, Nematoda, Copepoda, Ostracoda, Cladocera and Chironomidae grew faster after 2004, showing substantial increments in 2004-2007 and in 2011-2015. This trend mirrored the increment of the cumulative number of occurrences of the keywords relating to the "feeding habits" effect traits and the "diet" response traits. 

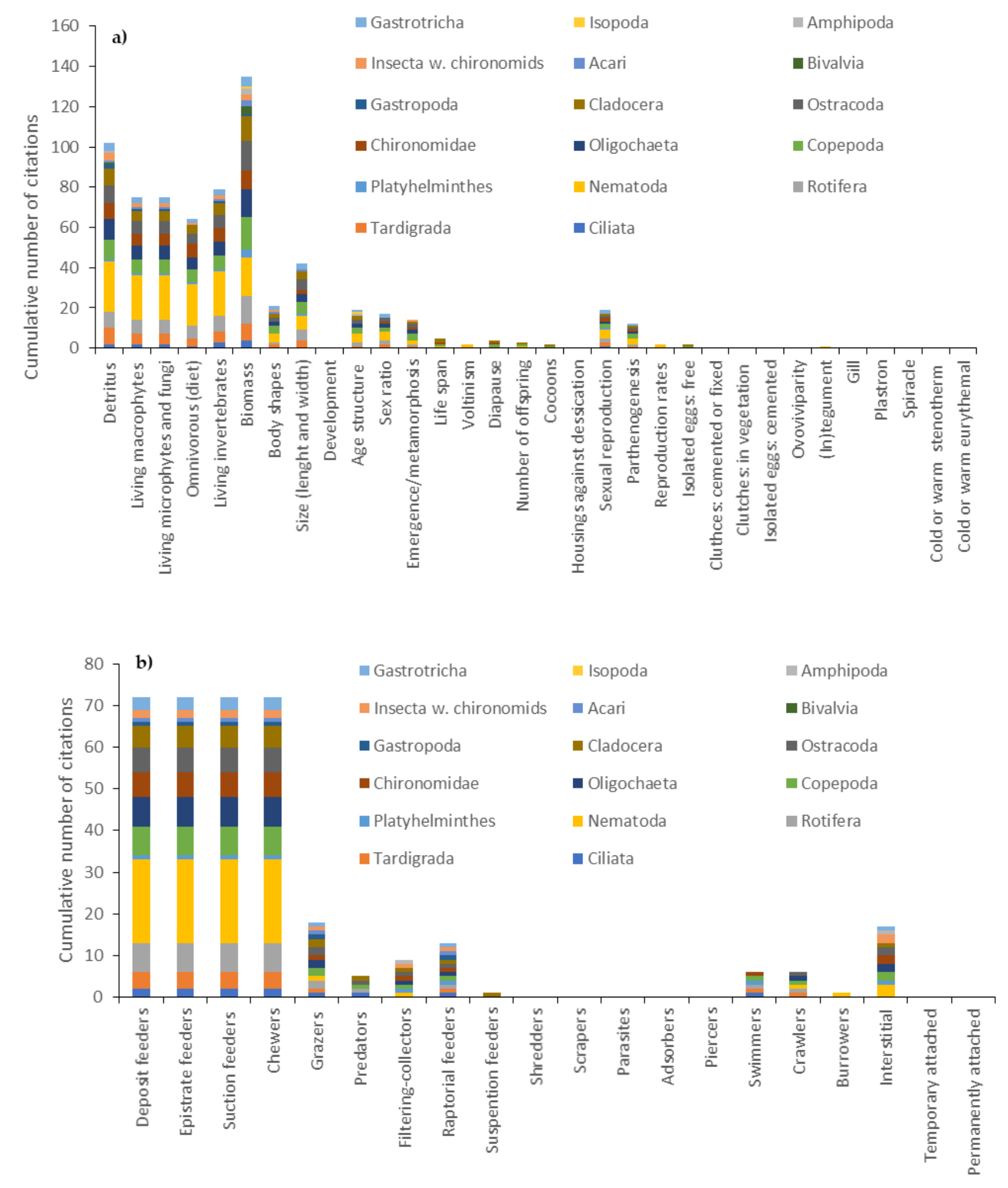

Figure 4. Cumulative number of citations of the 52 keywords associated with different meiofaunal taxa and related to (a) effect and (b) response traits. w.: without.

\section{Discussion}

According to Majdi et al. [19], a total of 795 peer-reviewed publications on meiofauna or meiobenthos were issued between 2000 and 2018, of which 174 studies dealt with freshwater while 621 with marine meiofauna. The first special issue on freshwater meiofauna, 
entitled "An introduction to a special issue on lotic meiofauna", was published by the journal Freshwater Biology in 2000 [36], followed by a dedicated book entitled "Freshwater Meiofauna" by Rundle et al. [37], mainly concerning lotic environments. In the present study, we observed that about $35 \%$ of the papers about freshwater meiofauna focused on the littoral zone of lakes. Most of these papers refer to observational studies carried out in Europe while genetics studies, as well as manipulated experiments aimed at investigating the effect of the anthropic impact on lake meiofauna, are poorly or completely unexplored.

The word "lake" was the most frequently mentioned in the abstracts of the papers examined in this study while the second was "nematod" which also appeared as the fourth most-cited keyword in the text-mining search carried out by Majdi et al. [19] concerning the freshwater meiofauna. Nematoda was the most studied taxon, both through taxonomyand trait-based approaches. Irrespective of the approach used, soft-bodied taxa such as Gastrotricha, Platyhelminthes, Rotifera and Protista Ciliata have been poorly studied, as it was also observed for the lotic meiofauna [19]. Traditional collection methods (including the use of the fixatives or flotation techniques), which are optimized for most of the meiofaunal taxa, are unsuitable for the preservation and identification of soft-bodied meiofauna. As a result, some taxa, such as Gastrotricha and Platyhelminthes, which must be assessed alive, are usually underestimated in conventional biodiversity surveys and ecological studies [26]. Although studies based on taxonomy approaches were more numerous than those based on traits, the Linnean shortfall of biodiversity (i.e., the large number of still undescribed species), has turned out to be an evident problem in studies concerning the meiofauna of the littoral zone of lakes. Recent studies suggested that metabarcoding may be an effective method to overcome the Linnean shortfall, mainly in the case of soft-bodied species [26]. However, it has been observed that for some phyla, such as Gastrotricha, Mollusca, Nemertea, and Xenacoelomorpha, the total estimated richness based on metabarcoding may be lower than that estimated by morphological taxonomy [38]. Besides, for organisms with an exoskeleton, such as nematodes and copepods, morphological taxonomy, which allows identification at low taxonomic ranks, generally genus or species, seems to be the most effective method to estimate biodiversity in contrast to metabarcoding because, for these taxa, the general reference libraries for DNA sequence data are poorly classified and some represent mislabeled fragments submitted to GenBank, misidentifications or contaminations (e.g., [38-40]). Active collaborations among morphology-based taxonomists and computational biologists should be supported to create reliable reference libraries across all taxonomic groups [41].

The trait analysis concerning the meiofauna of the littoral zone of lakes showed that the Raunkiaeran shortfall (i.e., the lack of information about biological traits) is still very pressing. This condition seems to be due to intrinsic difficulties related to the morphophysiological characteristics of the meiofauna, such as the very small size, which make the measurement of some traits complicated [38,42]. The most analyzed response trait was the one related to the diet of the animals. Despite our knowledge of the trophic ecology of meiofauna is still lagging behind that of zooplankton, macroinvertebrates and vertebrates, studies have inferred the diet of meiofauna using several techniques encompassing feeding observations, incubation experiments, gut content analyses as well as sophisticated analyses such as Raman spectrometry and nanoscale secondary ion mass spectrometry [21]. Thanks to these techniques, today we have at least an idea of the trophic ecology of many meiofaunal taxa and the results of the present study showed that this aspect was explored in many meiofaunal organisms of the lake littorals. From the frequency of occurrence of the keywords associated with this trait, it is clear that the diet of the meiofauna of the littoral zone of lakes is diversified, often omnivorous, comprising detritus, bacteria, fungi, micro-algae, flagellates, ciliates and other meiofaunal organisms.

Studies relating to the body size of the meiofauna of the lake littorals have been quite numerous, although much less than the diet. However, almost all the studies we examined primarily concerned biomass and did so on many organisms belonging to 16 taxa afferent to the lake meiofauna. In lotic environments, studies on the size-spectrum of the meiofauna, 
i.e., displaying of biomass in logarithmical intervals of body size, are common (e.g., [43]), while in groundwater $[14,44]$ and in lentic habitats they are much less considered. A further critical aspect is that, as regards lake meiofauna, only a few studies incorporated the species-specific biomass distribution at assemblage- and community-level and their variation within and among ecosystems (e.g., [23]).

The "life history" and "reproductive strategy" response traits have been very little investigated in the meiofauna of the littoral zone of lakes and, in any case, are mainly studied in Nematoda, Copepoda and Cladocera (e.g., [45-49]). Based on what has been observed for the meiofauna of lotic environments, it is assumed that these traits are very diversified also for the meiofauna of lakes due to the disparate number of taxa living in lakes. The "life history" trait was mainly investigated concerning the age structures and sex ratio in Nematoda [50-53], although these two aspects have proved to be effective in describing the life histories of groundwater copepods as well [14,30]. Furthermore, the study of temperature-dependent life-history traits, such as development, reproduction, and population growth rates, can be successfully carried out for some species of Copepoda in the laboratory, using mesocosms [54]. However, mesocosm studies with lake meiofauna are still very scarce or focused on Nematoda $[47,48]$.

The "feeding habits" was the most investigated class of effect traits which may be important for understanding the niche partition, the trophic interactions, and the way by which the structure of ecological networks is modeled. This trait has been studied on a multitude of meiofaunal taxa of the littoral zone of lakes, resulting, however, poorly investigated in soft-bodied taxa. The results of the present study show that most investigated taxa are "deposit feeders", "epistrate feeders", "suction feeders" or "chewers" while the "shredders", "scrapers", "parasites", "absorbers" and "piercers" keywords were not found at all. The fact that we did not find mentions of these keywords does not necessarily mean that these traits are not attributable to the meiofauna of the littoral zones of lakes. Rather, there may be intrinsic difficulties, often insurmountable, such as those related to the movements of these tiny organisms within the hidden benthic and inbenthic world made of sand grains, interstitial pores, biofilms and detrital particles, that make direct observations difficult in the natural environment (e.g., [19,23]). The same difficulties were due to the scarcity of studies related to the "locomotion and substrate relation" trait which has been investigated almost exclusively in nematodes, rotifers, some crustaceans and gastrotrichs e.g., $[55,56]$. Majdi et al. [21] suggested using laboratory populations with mesocosms to study certain traits that otherwise would not be directly observable in the field e.g., [57,58]. The results obtained also indicate that the traits receiving the least interest are respiration and thermal preference. These traits, on the other hand, require an in-depth study, especially considering the future climate change scenarios that will dramatically affect the coastal areas of lakes $[59,60]$. Even a small increase in temperature leads to a change in respiratory metabolism in some species of copepods [61] and significant variations in their survival [54]. It follows that studies on the respiration modes of different meiofaunal taxa of the littoral zone of lakes could be important to get an idea of meiofaunal resilience to drought and desiccation, or of the chances these organisms have to resist and to adapt to climate change. Schmid-Araya et al. [45] suggested that studies on the variation of biomass as a function of the temperature of lakes (but also of other aquatic ecosystems) should be considered a priority in the current context of climate change. Studying meiofaunal traits under climate change impact is of pivotal importance in order to understand the way by which climate-changing environments alter the functioning and the structures of freshwater ecosystems [2], especially in the littoral zone of lakes that is exposed to high variability of the abiotic parameters [15]. For instance, Jeppesssen et al. [61] argue that a change in the meiobenthic community structure of lakes is expected as a response to drought periods. Traits as biomass and sex ratio of Nematoda was used as indicators of the effect of lake trophic status [23,54], while locomotion and substrate relation of the meiobenthic organisms of the littoral zone of lake is considered an indicator of the adaptability to changing habitat conditions [53]. 


\section{Conclusions}

The present overview showed that the studies relating to the meiofauna of the littoral zone of lakes are still limited, especially when compared to those carried out on the lotic meiofauna and, to an even greater extent, to the marine ones. The knowledge of the functional traits is still fragmented and not suitable to draw general patterns. The studies carried out to date were mainly observational, concerned lakes of variable size and depth, were mostly located in Europe, and focused mainly on a few taxa, such as Nematoda and Copepoda. Soft-bodied taxa were poorly investigated, both through taxonomy- and trait-based approaches. Except for the feeding habits, as effect trait, and the diet, as response trait, the Raunkiaeran shortfall is very pronounced for all taxa but is more evident when considering the soft-bodied organisms. The motivation behind this deficiency concerns many aspects ranging from the high taxonomic expertise required (still not entirely replaceable by metabarcoding approaches) to the intrinsic difficulties of observing organisms of such a small size. Diet and feeding habits have been the most investigated traits. Future studies, perhaps focused on a specific dimensional category of lakes, could deepen the aspects related to these two traits, in order to provide information on the food web structures. The relationship among functional traits and temperature has not been sufficiently explored and formalized. This represents a major gap that needs to be urgently addressed, given the severity of future climate change scenarios affecting mainly the most vulnerable environments such as the littoral zone of lakes. Finally, laboratory studies, with the aid of microcosms and the most modern microscopy techniques, could achieve results that were not conceivable twenty years ago. Research funding should, therefore, be primarily directed towards these basic studies.

Supplementary Materials: The following xlsb document named "Cifoni et al._SF" is available online at https:/ / www.mdpi.com/2073-4441/13/4/473/s1.

Author Contributions: M.C.: methodology, formal analysis, investigation, data curation, writingoriginal draft; T.D.L.: conceptualization, methodology, validation, writing-review \& editing; D.M.P.G.: validation, writing-review \& editing; A.B.: validation, writing-review \& editing, resources, funding acquisition. All authors have read and agreed to the published version of the manuscript.

Funding: This research was funded by INTERREG project V-A ITALIA-SVIZZERA 2014-2020, Parchi Verbano Ticino, ID 481668.

Institutional Review Board Statement: Not applicable.

Informed Consent Statement: Not applicable.

Data Availability Statement: Data is contained within the article or supplementary material.

Acknowledgments: We thank Lyudmilla Kamburska, Silvia Zaupa and Daniele Paganelli of CNRIRSA for the stimulating discussions about trait-based approaches. We are also indebted to two anonymous reviewers for their helpful comments.

Conflicts of Interest: The authors declare no conflict of interest.

\section{References}

1. Cantonati, M.; Poikane, S.; Pringle, C.M.; Stevens, L.E.; Turak, E.; Heino, J.; Richardson, J.S.; Bolpagni, R.; Borrini, A.; Cid, N.; et al. Characteristics, Main Impacts, and Stewardship of Natural and Artificial Freshwater Environments, Consequences for Biodiversity Conservation. Water 2020, 12, 260. [CrossRef]

2. Reid, A.J.; Carlson, A.K.; Creed, I.F.; Eliason, E.J.; Gell, P.A.; Johnson, P.T.J.; Kidd, K.A.; MacCormack, T.J.; Olden, J.D.; Ormerod, S.J.; et al. Emerging threats and persistent conservation challenges for freshwater biodiversity. Biol. Rev. 2020, 94, 849-873. [CrossRef] [PubMed]

3. Dudgeon, D.; Arthington, A.H.; Gessner, M.O.; Kawabata, Z.; Knowler, D.J.; Lévêque, C.; Naiman, R.J.; Prieur-Richard, A.H.; Soto, D.; Stiassny, M.L.; et al. Freshwater biodiversity: Importance, threats, status and conservation challenges. Biol. Rev. Camb. Philos. Soc. 2006, 81, 163-182. [CrossRef]

4. Craig, L.; Olden, J.D.; Arthington, A.H.; Strayer, D.L.; Tank, J.L.; West, A.O.; Wooten, M.S. Meeting the challenge of interacting threats in freshwater ecosystems: A call to scientists and managers. Elementa 2017, 5, 72. [CrossRef] 
5. Geist, J. Integrative freshwater ecology and biodiversity conservation. Ecol. Indic. 2011, 11, 1507-1516. [CrossRef]

6. Trishala, K.P.; Deepak, R.; Agrawal, Y.K. Bioindicators: The natural indicator of environmental pollution. Front. Life Sci. 2016, 9 , 110-118. [CrossRef]

7. Santos, J.M.; Ferreira, M.T. Use of Aquatic Biota to Detect Ecological Changes in Freshwater: Current Status and Future Directions. Water 2020, 12, 1611. [CrossRef]

8. Nock, C.A.; Vogt, R.J.; Beisner, B.E. Functional Traits. In eLS; John Wiley \& Sons, Ltd.: Chichester, UK, 2016. [CrossRef]

9. Suding, K.N.; Lavorel, S.; Chapin, F.S.; Cornelissen, J.H.C.; Díaz, S.; Garnier, E.; Goldberg, D.; Hooper, D.U.; Jackson, S.T.; Navas, M.-L. Scaling environmental change through the community-level: A trait-based response-and-effect framework for plants. Glob. Chang. Biol. 2008, 14, 1125-1140. [CrossRef]

10. Moretti, M.; Dias, A.T.C.; de Bello, F.; Altermatt, F.; Chown, S.L.; Azcárate, F.M.; Bell, J.R.; Fournier, B.; Hedde, M.; Hortal, J.; et al. Handbook of protocols for standardized measurement of terrestrial invertebrate functional traits. Funct. Ecol. 2017, 31, 558-567. [CrossRef]

11. Hevia, V.; Martín-López, B.; Palomo, S.; García-Llorente, M.; de Bello, F.; González, J.A. Trait-based approaches to analyze links between the drivers of change and ecosystem services: Synthesizing existing evidence and future challenges. Ecol. Evol. 2017, 7, 831-844. [CrossRef] [PubMed]

12. Culp, J.M.; Armanini, D.G.; Dunbar, M.J.; Orlofske, J.M.; Poff, N.L.; Pollard, A.I.; Yates, A.G.; Hose, G.C. Incorporating traits in aquatic biomonitoring to enhance causal diagnosis and prediction. Integr. Environ. Assess. Manag. 2011, 7, 187-197. [CrossRef]

13. Usseglio-Polatera, P.; Bournaud, M.; Richoux, P.; Tachet, H. Biological and ecological traits of benthic freshwater macroinvertebrates: Relationships and definition of groups with similar traits. Freshw. Biol. 2001, 43, 175-205. [CrossRef]

14. Di Lorenzo, T.; Fiasca, B.; Di Cicco, M.; Galassi, D.M.P. The impact of nitrate on the groundwater assemblages of European unconsolidated aquifers is likely less severe than expected. Environ. Sci. Pollut. Res. 2020. [CrossRef]

15. Van den Brink, P.J.; Baird, D.J.; Baveco, H.; Focks, A. The use of traits-based approaches and eco(toxico)logical models to advance the ecological risk assessment framework for chemicals. Integr. Environ. Assess. Manag. 2013, 9, e47-e57. [CrossRef] [PubMed]

16. Rico, A.; Van den Brink, P.J.; Gylstra, R.; Focks, A.; Brock, T.C. Developing ecological scenarios for the prospective aquatic risk assessment of pesticides. Integr. Environ. Assess. Manag. 2016, 12, 510-521. [CrossRef] [PubMed]

17. Feld, C.K.; Hering, D. Community structure or function: Effects of environmental stress on benthic macroinvertebrates at different spatial scales. Freshw. Biol. 2007, 52, 1380-1399. [CrossRef]

18. Giere, O. Meiobenthology: The Microscopic Motile Fauna of Aquatic Sediments, 2nd ed.; Springer-Verlag: Berlin/Heidelberg, Germany, $2016 ;$ p. 527.

19. Majdi, N.; Schmid-Araya, J.; Traunspurger, W. Preface: Patterns and processes of meiofauna in freshwater ecosystems. Hydrobiologia 2020, 847, 2587-2595. [CrossRef]

20. Schmid-Araya, J.M.; Schmid, P.E.; Tod, S.P.; Esteban, G.F. Trophic positioning of meiofauna revealed by stable isotopes and food-web analyses. Ecology 2016, 97, 3099-3109. [CrossRef] [PubMed]

21. Majdi, N.; Schmid-Araya, J.M.; Traunspurger, W. Examining the diet of meiofauna: A critical review of methodologies. Hydrobiologia 2020, 847, 2737-2754. [CrossRef]

22. Rebecchi, L.; Boschetti, C.; Nelson, D.R. Extreme tolerance in meiofaunal organisms: A case study with tardigrades, rotifers and nematodes. Hydrobiologia 2020, 847, 2779-2799. [CrossRef]

23. Traunspurger, W.; Wilden, B.; Majdi, N. An overview of meiofaunal and nematode distribution patterns in lake ecosystems differing in their trophic state. Hydrobiologia 2020, 847, 2665-2679. [CrossRef]

24. Ristau, K.; Spann, N.; Traunspurger, W. Species and trait compositions of freshwater nematodes as indicative descriptors of lake eutrophication. Ecol. Indic. 2015, 53, 196-205. [CrossRef]

25. Kurashov, E.A. The role of meiobenthos in lake ecosystems. Aquat. Ecol. 2002, 36, 447-463. [CrossRef]

26. Fonseca, G.; Fontaneto, D.; Di Domenico, M. Addressing biodiversity shortfalls in meiofauna. J. Exp. Mar. Biol. Ecol. 2018, 502, 26-38. [CrossRef]

27. Poff, N.L.; Olden, J.D.; Vieira, N.K.; Finn, D.S.; Simmons, M.P.; Kondratieff, B.C. Functional trait niches of North American lotic insects: Traits-based ecological applications in light of phylogenetic relationships. J. N. Am. Benthol. Soc. 2006, 25, 730-755. [CrossRef]

28. Brown, L.E.; Milner, A.M. Rapid loss of glacial ice reveals stream community assembly processes. Glob. Change Biol. 2012, 18, 2195-2204. [CrossRef]

29. Dunscombe, M.; Robertson, A.; Peralta-Maraver, I.; Shaw, P. Community structure and functioning below the streambed across contrasting geologies. Sci. Total Environ. 2018, 630, 1028-1035. [CrossRef] [PubMed]

30. Di Lorenzo, T.; Murolo, A.; Fiasca, B.; Tabilio Di Camillo, A.; Di Cicco, M.; Galassi, D.M.P. Potential of A Trait-Based Approach in the Characterization of An N-Contaminated Alluvial Aquifer. Water 2019, 11, 2553. [CrossRef]

31. Pozsgai, G.; Lövei, G.L.; Vasseur, L.; Gurr, G.; Batáry, P.; Korponai, J.; Littlewood, N.A.; Liu, J.; Móra, A.; Obrycki, J.; et al. Comparative analysis reveals irreproducibility in searches of scientific literature. bioRxiv 2020. Available online: https://doi.org/ 10.1101/2020.03.20.997783 (accessed on 2 January 2021).

32. R Core Team. R: A Language and Environment for Statistical Computing. R vs. 3.5 Foundation for Statistical Computing, Vienna, Austria. 2019. Available online: https:/ / www.R-project.org/ (accessed on 2 January 2021). 
33. Feinerer, I.; Hornik, K. tm: Text Mining Package. R Package Version 0.7-7. 2019. Available online: https://cran.r-project.org/ web/packages/tm/index.html (accessed on 2 January 2021).

34. Bouchet-Valat, M. SnowballC: Snowball Stemmers Based on the C 'libstemmer' UTF-8 Library. R Package Version 0.6.0. 2019. Version 0.6.0. Available online: https:/ /CRAN.R-project.org/package=SnowballC (accessed on 2 January 2021).

35. Fellows, I. Wordcloud: Word Clouds. R Package Version2.6. 2018. Available online: https: $/ /$ CRAN.Rproject.org $/$ package= wordcloud (accessed on 2 January 2021).

36. Robertson, A.L.; Rundle, S.D.; Schmid-Araya, J.M. An introduction to a special issue on lotic meiofauna. Freshw. Biol. 2000, 44, 1-3. [CrossRef]

37. Rundle, S.D.; Robertson, A.L.; Schmid-Araya, J.M. Freshwater Meiofauna, 1st ed.; Backhuys Publishers: Leiden, The Netherlands, 2002; pp. 1-396. [CrossRef]

38. Leasi, F.; Sevigny, J.L.; Laflamme, E.M. Biodiversity estimates and ecological interpretations of meiofaunal communities are biased by the taxonomic approach. Commun. Biol. 2018, 1, 112. [CrossRef]

39. Sinniger, F.; Pawlowski, J.; Harii, S.; Gooday, A.J.; Yamamoto, H.; Chevaldonné, P.; Cedhagen, T.; Carvalho, G.; Creer, S. Worldwide analysis of sedimentary DNA reveals major gaps in taxonomic knowledge of deep-sea benthos. Front. Mar. Sci. $2016,3,92$. [CrossRef]

40. Khodami, S.; McArthur, J.V.; Bercial, L.B.; Arbizu, P.M. Retraction Note: Molecular Phylogeny and Revision of Copepod Orders (Crustacea: Copepoda). Sci. Rep. 2017, 7, 9164. [CrossRef] [PubMed]

41. Lopez, J.V. The global invertebrate genomics alliance (GIGA): Developing community resources to study diverse invertebrate genomes. J. Hered. 2014, 105, 1-18. [CrossRef]

42. Robertson, A.L.; Milner, A.M. The influence of stream age and environmental variables in structuring meiofaunal assemblages in recently deglaciated streams. Limnol. Oceanogr. 2006, 51, 1454-1465. [CrossRef]

43. Schmid, P.E.; Schmid-Araya, J.M.; Tokeshi, M. The scaling of biomass variance across trophic levels in stream species communities: A macroecological approach. Hydrobiologia 2020, 847, 2705-2723. [CrossRef]

44. Di Lorenzo, T.; Fiasca, B.; Di Camillo Tabilio, A.; Murolo, A.; Di Cicco, M.; Galassi, D.M.P. The weighted Groundwater Health Index (wGHI) by Korbel and Hose (2017) in European groundwater bodies in nitrate vulnerable zones. Ecol. Indic. 2020, 116, 106525. [CrossRef]

45. Schmid-Araya, J.M.; Schmid, P.E.; Majdi, N.; Traunspurger, W. Biomass and production of freshwater meiofauna: A review and a new allometric model. Hydrobiologia 2020, 847, 2681-2703. [CrossRef]

46. Sarvala, J. Ecology and role of benthic copepods in northern lakes. J. Mar. Syst. 1996, 15, 75-86. [CrossRef]

47. Ristau, K.; Traunspurger, W. Relation between nematode communities and trophic state in southern Swedish lakes. Hydrobiologia 2011, 663, 121-133. [CrossRef]

48. Ristau, K.; Faupel, M.; Traunspurger, W. The effects of nutrient enrichment on a freshwater meiofaunal assemblage. Freshwat. Biol. 2012, 57, 824-834. [CrossRef]

49. Pinel-Alloul, B.; Alekseev, V.R. The Role of Biotic and Abiotic Interactions in Summer Diapause in Cyclopoids: Conceptual Model and Field Validation in Southern Quebec Boreal Lakes. In Dormancy in Aquatic Organisms. Theory, Human Use and Modeling. Monographiae Biologicae; Alekseev, V., Pinel-Alloul, B., Eds.; Springer: Cham, Switzerland, 2019; Volume 92. [CrossRef]

50. Traunspurger, W.; Drews, C. Vertical distribution of benthic nematodes in an oligotrophic lake: Seasonality, species and age segregation. Hydrobiologia 1996, 331, 33-42. [CrossRef]

51. Michiels, I.C.; Traunspurger, W. A three-year study of seasonal dynamics of a zoobenthos community in a eutrophic lake. Nematology 2004, 6, 655-669. [CrossRef]

52. Peters, L.; Traunspurger, W. Species distribution of free-living nematodes and other meiofauna in littoral periphyton communities of lakes. Nematology 2005, 7, 267-280. [CrossRef]

53. Schroeder, F.; Peters, L.; Traunspurger, W. Nematodes in the periphyton of lakes: Variations in diversity, species composition, age structure, and sex ratio. Internat. Rev. Hydrobiol. 2013, 98, 322-333. [CrossRef]

54. Cifoni, M.; Galassi, D.M.P.; Faraloni, C.; Di Lorenzo, T. Test procedures for measuring the (sub)chronic effects of chemicals on the freshwater cyclopoid Eucyclops serrulatus. Chemosphere 2017, 173, 89-98. [CrossRef] [PubMed]

55. Balsamo, M.; Fregni, E. Gastrotrichs from interstitial fresh water, with a description of four new species. Hydrobiologia 1995, 302, 163-175. [CrossRef]

56. Traunspurger, W. The biology and ecology of lotic nematodes. Freshw. Biol. 2000, 44, 29-45. [CrossRef]

57. Fueser, H.; Majdi, N.; Haegerbaeumer, A.; Pilger, C.; Hachmeister, H.; Greife, P.; Huser, T.; Traunspurger, W. Analyzing life-history traits and lipid storage using CARS microscopy for assessing effects of copper on the fitness of Caenorhabditis elegans. Ecotoxicol. Environ. Safe. 2018, 156, 255-262. [CrossRef] [PubMed]

58. Majdi, N.; Traunspurger, W.; Fueser, H.; Gansfort, B.; Laffaille, P.; Maire, A. Effects of a broad range of experimental temperatures on the population growth and body-size of five species of free-living nematodes. J. Therm. Biol. 2019, 80, 21-36. [CrossRef]

59. Fenoglio, S.; Bo, T.; Cucco, M.; Mercalli, L.; Malacarne, G. Effects of global climate change on freshwater biota: A review with special emphasis on the Italian situation. Ital. J. Zool. 2010, 77, 374-383. [CrossRef]

60. Jeppesen, E.; Meerhoffm, M.; Davidson, T.A.; Trolle, D.M.; Søndergaard, M.; Lauridsen, T.L.; Beklioglu, M.; Brucet, S.; Volta, P.; González-Bergonzoni, I.; et al. Climate change impacts on lakes: An integrated ecological perspective based on a multi-faceted 
approach, with special focus on shallow lakes. J. Limnol. 2014, 73, 88-111. Available online: https://www.jlimnol.it/index.php/ jlimnol/article/view/jlimnol.2014.844 (accessed on 2 January 2021). [CrossRef]

61. Di Lorenzo, T.; Galassi, D.M.P. Effect of Temperature Rising on the Stygobitic Crustacean Species Diacyclops belgicus: Does Global Warming Affect Groundwater Populations? Water 2017, 9, 951. [CrossRef] 